\title{
The Financial Value of Postsecondary Education
}

\author{
Bruce D. Niendorf \\ University of Wisconsin Oshkosh
}

\author{
Kristine L. Beck \\ California State University, Northridge
}

\begin{abstract}
Earning a postsecondary degree involves paying for tuition, fees, books, supplies, and living costs. While in school students forgo full-time job earnings; and, after earning a degree, they may pay interest on student loans for many years. This study examines 115 Wisconsin degree/school combinations to identify the value remaining after paying the costs of a postsecondary degree - the Education Value that is above and beyond what they would have earned with a high school diploma. We find the best combination delivers an additional \$1,694,086 in value across a lifetime, and the least value-added bachelor's degree combination still delivers $\$ 378,466$. All combinations are investments in human capital that significantly outperform the long-term average of the U.S. stock market and may be the best investment many people ever make.
\end{abstract}

Keywords: education value, return on investment, student debt

\section{INTRODUCTION}

In 2016, the Council of Economic Advisors estimated that in 2015, federal student loans helped 9 million Americans invest in post-secondary education. This study finds that these investments may be the best investment many people make. Over their lifetimes, the median recipient of a Wisconsin postsecondary degree earns $\$ 4.75$ million more than the average high school graduate. Society also benefits from these investments through higher tax revenues, improvements in health, higher rates of volunteering and voting, and lower levels of criminal behavior. ${ }^{1}$ Valero and Van Reenen (2019), using international data, find that increases in the number of universities are positively related to future growth of GDP per capita in both the university region and neighboring regions. They conclude part of that growth is due to increased supply of human and intellectual capital.

To receive the benefits from postsecondary education, students face many upfront costs. The average cost of a four-year bachelor's degree from the University of Wisconsin Madison, for example, is just under $\$ 60,000$. If a 20 -year-old invested that same amount in a retirement account instead of paying for a fouryear degree from the UW Madison, that person could anticipate an account balance of over \$8,607,271 by age $68 .^{2}$ This example also assumes a student has $\$ 60,000$ to invest at age 20. Lacking access to this amount of money from other sources, most students pay for their education using student loans, the interest on which adds further cost to their education.

Student debt also has a profound impact on retirement. Instead of being able to start saving for retirement early, thereby taking advantage of the most value-adding years of saving through compounding, 
students with debt direct at least some of what they might otherwise have saved for their future toward paying off their past. From 1971-2020, the S\&P 500 index has averaged $10.9 \%$ return per year. ${ }^{3}$ At $10.9 \%$, every dollar a person saves at age 22 is multiplied 117 times by retirement at age 68; thus, $\$ 1,000$ saved becomes $\$ 117,000$. If the average student takes 18.5 years to pay off their loans, they need to wait until age 40.5 to be able to direct their loan payments into retirement savings. By age 40.5, every dollar they save is multiplied only 17 times, thereby dramatically reducing their ability to provide for their own retirements.

Making an informed education investment decision requires considering the upfront costs of a postsecondary degree, the forgone earnings a student could have earned during their years earning a postsecondary degree, interest costs and payments of student loans, and the resulting increased earnings, which are spread out over a lifetime. After considering these financial costs and benefits, this study finds that the median value added by $115 \mathrm{Wisconsin}$ degree/school combinations is $\$ 861,778$. Thus, after paying the costs of education, forgoing earnings while a student, and paying interest on student loans, the median Wisconsin degree/school combination adds value equivalent to receiving \$861,778 upon high school graduation in addition to earning what the average high school graduate earns in their lifetimes.

\section{BACKGROUND}

\section{Student Debt}

Student debt levels are increasing dramatically; U.S. student debt more than doubled from 2010 to 2020 , and now totals more than $\$ 1.7$ billion owed. ${ }^{4}$ By the end of 2021, 43.2 million students will have accumulated an average debt of $\$ 39,351$ to meet their postsecondary education costs. ${ }^{5}$ These borrowers are in the majority; $54 \%$ of 2018 college students had to borrow to pay for their educations. ${ }^{6}$ Finally, this debt has long-term financial effects. According to a 2019 study from New York Life, the average student borrower reported taking 18.5 years to pay off their student loans.

Student debt has additional effects that reach beyond immediate financial implications. Chakrabarti et al. (2020) examine the impact of college tuition on student debt and human capital accumulation. They find that an increase of $\$ 5,000$ in tuition reduces the probability of graduating by $3.1 \%$ and increases student debt by $\$ 1,480$. They also find that higher tuition reduces the probability of credit-constrained students obtaining an undergraduate degree. Lucca et al. (2019) discover a link between tuition and federal student loan caps, which affects all students, not just those with federal student loans. This effect is more pronounced for 2-year, for-profit, and elite institutions.

Zhang (2013) finds that college debt has a significant negative influence on graduate school attendance and that debt has no effects on early career choices for both public and private college students. Contrary to Zhang, Rothstein and Rouse (2011) argue debt causes graduates to choose substantially higher-salary jobs, and that debt affects students' academic decisions during college. Ji (2021) also finds student loans have a significant effect on borrowers' job search decisions. Ji determines that due to liquidity constraints under fixed repayment plans, loans have a significant effect on career choices, unemployment duration, and wage income.

Looney and Yannelis (2019) show that increases in credit limits and availability result in rising balances, and that the share of borrowers with very large balances has surged. They also find that repayment rates slowed significantly between 1990 and 2014, with the fraction of borrowers owing more than $\$ 50,000$ doubling during that period. Similarly, Schanzenbach et al. (2017) demonstrate that student financial aid has increased dramatically over the past 15 years, while state direct aid to institutions has stagnated. They also find that $90 \%$ of undergraduate borrowers borrow less than $\$ 40,000$, and that most defaulters have less than $\$ 10,000$ in student loan debt outstanding.

Another stream of research demonstrates that student loan debt is worse for either those who do not graduate or those who earn a degree from a lower-ranked school. Eaton et al. (2020) find private equityowned schools are associated with lower graduation rates, lower loan repayment rates, and lower earnings among graduates. Looney and Yannelis (2015) find that student loan defaults often are due to ability to pay rather than the size of the loan - many had dropped out before graduation, or failed to find a decent job after graduation, or were economically disadvantaged before college. They also find borrowers at for-profit 
schools have poor repayment outcomes and lower labor market outcomes compared to borrowers at more selective institutions.

Recent research by the Life Insurance Marketing and Research Association (LIMRA) finds other longterm consequences associated with using loans to pay for education. Holland (2015) describes several results of LIMRA's research. First, LIMRA found that $\$ 30,000$ in student debt can reduce a person's 401(k) balance at retirement by as much as $\$ 325,000$. LIMRA also found that student debt is associated with reduced home ownership for people in their twenties: $52.3 \%$ of people with student loan debt own homes versus $58.8 \%$ home ownership by those without student loans. It appears that many students with debt are missing out or getting a later start on building equity through home ownership. Finally, LIMRA found that not only students shoulder the burden of student loans. This burden is shared increasingly by people aged 55-64. LIMRA research finds that in 1989, just 4\% of people aged 55-64 had education debt. By 2013, this figure had grown to $30 \%$. Clearly, students and those that support them are willing to sacrifice and invest huge amounts in their education. The increasing long-reaching financial consequences of students' education decisions makes making a wise financial choice increasingly important.

\section{Student Attributes}

Although all students can benefit from a post-secondary degree, the amount they benefit financially depends on their background and circumstances. Dale and Krueger (2011) examine the question of whether attending a highly selective school results in higher future earnings. For their overall sample, including more than 18,000 students, they find that returns to college selectivity are generally indistinguishable from zero when controlling for student SAT score and variables commonly controlled for such as race, gender, family income, whether a student is a student athlete, and the number of schools to which the student applied. In other words, as stated by Thompson (2018), this finding suggests that the talents and ambitions of individual students are worth more than the resources and renown of elite schools. The person you're becoming at age 18 is more important than the school you graduate from at age 22. Thus, according to Dale and Kruger, it doesn't really matter which school the average student attends.

Although earnings may not be affected by school choice for students as a whole group, there do appear to be important differences for subgroups based on gender, race, and educational attainment of a person's family. Cooper and Cohn's (1997) findings vary considerably across both race-sex groups and among various analytical techniques and assumptions. Although Ge et al. (2019) find no significant effect of college selectivity on earnings and family outcomes for men, the results are quite different for women. They find that attending a school with a 100-point higher average SAT score increases women's earnings by $14 \%$, while also reducing their likelihood of marriage by 4\%. Dale and Krueger (2011) find a significant positive effect between school selectivity and earnings for Black and Hispanic students as well as for students from families with parents with less than 16 years of schooling, but no relationship between school selectivity and future earnings for white men. In summary, previous research suggests that although all students benefit financially from earning a post-secondary degree, the amount that they benefit depends, at least in part, on their race and gender.

\section{College Return on Investment}

Several studies show positive returns from a college education. Avery and Turner (2012) conclude that college is a good investment, but that it also is a lottery with significant high- and low-end risk in the returns to education. Barrow and Malamud (2015) conclude college is a worthwhile investment on average. Abel and Deitz (2019) find that the average rate of return for a bachelor's degree has decreased, but still is about $14 \%$ and a good investment. They also conclude that college graduates earn a substantial wage premium, and that the premium fluctuates over time, but is fairly steady at $\$ 30,000$ to $\$ 35,000$ a year after 2000 . Giani, et al. (2019) examine outcomes for Texas high school students and find that students with some college are more likely to be employed 15 years after high school graduation and tend to earn more than their non-college counterparts.

Other studies find varied results. Cappelli (2020) considers whether college costs are paid by the students and their families, and find return results mixed, depending on the college. Lobo and Burke- 
Smalley (2018) incorporate time to graduation and the financing method and find that the value of a college education is positive regardless of how a degree is financed, but declines as the time-to-graduation increases. They argue that for students at the lower end of the ability distribution and in some areas of study, a college degree may not be a good financial decision.

\section{This Study}

Although there are many nonfinancial benefits of postsecondary education, the rapid growth in student debt levels and increasing competition between postsecondary education providers, including for-profit colleges, suggests that financial considerations are of increasing importance. The question this study addresses is: What financial value do Wisconsin students receive in return for their investment in obtaining a post-secondary degree? Rate of return and value-added are fundamental decision criteria for making any investment, yet thousands of students make education investment decisions concerning potentially huge financial implications without this basic information. This study provides cost, beginning salary, total value-added, value-added per hour of study, and return on human capital investment in education for 11 different academic disciplines offered by a wide range of colleges and universities in Wisconsin.

We extend Lobo and Burke-Smalley (2018) to explicitly consider costs, cost per hour of study, and benefits across different majors. Like Arias and McMahon (2001), we consider growth rates for both costs and future income. Their approach, however, focuses on national or statewide decisions of whether to invest in education at different levels rather than a student using the information to decide whether to go to college. Our focus is on determining the value-added of a college education to the student.

\section{DATA}

We consider the cost of earning a degree for art, business, communication, computer science, education, engineering, humanities, math, health, science, and social sciences offered by colleges and universities in Wisconsin. Data are collected on the cost of earning a degree for each school included in the study, the annual rate of growth in school costs, beginning salaries earned by students by school and by degree area, and rate of growth in salaries. Data on tuition, fees, books, and supplies are collected from the U.S. Department of Education Institute of Education Sciences National Center for Education Statistics (NCES), which provides education costs via CollegeNavigator. The cost growth rate is from Vanguard Group's College Cost Planner, salary growth rates are collected from the U.S. Bureau of Labor Statistics data on All Civilian Total compensation for All occupations, and beginning salaries are from the 2019 College Salary Report on payscale.com.

Costs are total costs, not netted out by financial aid or grants for in-state students. Data are collected for all Wisconsin schools available on CollegeNavigator. Where possible, we verify the costs identified on the CollegeNavigator site using costs listed on each school's website and find no significant discrepancies between the two sources.

Costs of living are not included to maintain comparability to the value obtained by someone with only a high school education because people must pay living costs regardless of whether they are working or studying. We assume living costs to be the same under both scenarios. and therefore, a wash. The growth rate applied to costs, 5\%, is intended to reflect the expected long-term growth rate in college costs. The value is from Vanguard Group's College Cost Planner; this long-term estimate is similar to estimates from other sources.

Beginning salaries and early career pay are provided by state, school, and degree in the 2019 College Salary Report on payscale.com. For each school and degree area, we use the median early career pay (first $0-5$ years of work life) to represent the beginning salary earned by the average student. We use this value rather than the actual starting pay earned by the average student immediately upon graduation to avoid error due to students not working in a capacity that fully reflects their post-secondary degree immediately upon graduation. We apply an average salary growth rate of $2.55 \%$ to reflect long-term salary growth, calculated using U.S. Bureau of Labor Statistics data on All Civilian Total compensation for All occupations for the period 2004-2019. As job markets continue to become more global, we use national average data rather 
than data specific to Wisconsin residents. We were unable to find data-specific rates to individual degree areas.

Table 1 presents the annual cost of attendance for the sixteen Wisconsin schools with data available on CollegeNavigator. The average in-state annual cost for tuition, books, supplies, and other costs (not including room and board) for an in-state student to attend a Wisconsin postsecondary institution for the 2018-19 academic year ranges from $\$ 10,014$ for Fox Valley Technical College to $\$ 34,000$ for Concordia University. A student, therefore, may spend \$20,028 for a two-year degree from Fox Valley Technical College to $\$ 59,644$ for a four-year degree from University of Wisconsin Madison, not including annual cost increases.

TABLE 1

ANNUAL COST OF ATTENDANCE 2018-2019 ACADEMIC YEAR

\begin{tabular}{|c|c|c|c|c|}
\hline School & $\begin{array}{c}\text { In-State } \\
\text { Tuition }\end{array}$ & $\begin{array}{l}\text { Books and } \\
\text { Supplies }\end{array}$ & Other & Total \\
\hline Concordia University & $\$ 29,450$ & $\$ 1,750$ & $\$ 2,800$ & $\$ 34,000$ \\
\hline Marian University & 27,400 & 800 & 3,590 & 31,790 \\
\hline UW Madison & 10,555 & 1,200 & 3,156 & 14,911 \\
\hline UW Milwaukee & 9,588 & 800 & 3,370 & 13,758 \\
\hline UW Stout & 9,457 & 416 & 3,176 & 13,049 \\
\hline UW Superior & 8,126 & 1,000 & 3,793 & 12,919 \\
\hline UW Eau Claire & 8,820 & 400 & 3,316 & 12,536 \\
\hline UW Parkside & 7,389 & 700 & 4,038 & 12,127 \\
\hline UW Green Bay & 7,878 & 800 & 3,350 & 12,028 \\
\hline UW Platteville & 7,796 & 560 & 3,365 & 11,721 \\
\hline UW Stevens Point & 8,239 & 300 & 3,108 & 11,647 \\
\hline UW Whitewater & 7,692 & 600 & 3,150 & 11,442 \\
\hline UW River Falls & 8,025 & 370 & 3,016 & 11,411 \\
\hline UW Oshkosh & 7,621 & 1,000 & 2,780 & 11,401 \\
\hline UW LaCrosse & 9,107 & 120 & 1,956 & 11,183 \\
\hline Fox Valley Technical College & 4,436 & 1,939 & 3,639 & 10,014 \\
\hline Median & & & & $\$ 12,078$ \\
\hline
\end{tabular}

\section{METHODOLOGY}

Both Net Present Value (NPV) and the Internal Rate of Return (IRR) have been used to evaluate the return on post-secondary degree investment. ${ }^{7} \mathrm{NPV}$ is calculated by netting the present value of future costs and benefits, and IRR identifies the implied rate of return on investments. We use the NPV approach because it provides a direct measure of how much value a post-secondary education is expected to provide the student. Although the total cost of attending a school is an important consideration, the payoff from the investment also is important. When considering both cost and benefits, it is easily possible that a relatively expensive school adds enough to students' future earning power that, in terms of return on investment, it far outperforms what may be smaller increased future earning power added by a relatively inexpensive school. It is critical to consider both costs and benefits together to assess the financial attractiveness of the choices available to Wisconsin students. The difference between costs and benefits, adjusted for time, can be thought of as time-adjusted profit, and is essentially what NPV measures.

We also calculate first year cost, beginning salary, IRR, and Education Value, or value-added to the student. Education Value is value over and above what the average high school graduate would earn without a post-secondary degree. Education Value is defined as total value minus the value of a high school 
education, and represents the value the average student adds by obtaining a post-secondary degree. Valueadded per hour of study needed to earn a post-secondary degree also is provided.

Our approach considers both costs and future income in detail. College costs are assumed to grow at $5 \%$ per year throughout the four years of the degree. Career income is assumed to begin in year 5 for bachelor's degrees and year 3 for technical degrees. Future costs and cash flows are adjusted for growth, discounted to the present, and then netted against each other. Cash flows are discounted to the present using a discount rate of $5.68 \%$, the average rate of return on long-term investment grade bonds. This rate reflects a modest amount of risk, which is intended to be similar to the expected variability in a person's lifetime earnings stream. Data to calculate this rate were obtained from The Vanguard Group. All returns reported reflect annual compounding.

Future incomes through age 68 are expected to grow at $2.55 \%$ per year. The Social Security Administration currently defines the Full Retirement Age (FRA) as 67 years for those born in 1960 or later. We hedge the risk of future increases in the FRA by increasing the assumed retirement age to 68 years; variations of up to several years in the actual retirement age for today's college students make relatively small differences in Education Value.

\section{RESULTS}

In this study, we calculate the value of a bachelor's degree in the disciplines of art, business, communication, computer science, education, engineering, humanities, math, health, science, and social studies, as well as the values of associate degrees in business, computer science, engineering, and health. Degree granting institutions are Wisconsin state universities, Fox Valley Technical College, and private schools Concordia University and Marian University.

To establish a benchmark for the post-secondary degree values, we identify the financial value of a high school degree. The current value of the earnings stream of those with a high school degree is approximately $\$ 766,566$. To earn this value, the average Wisconsin high school graduate starts working right after completing high school at a salary of $\$ 30,588$ per year, which is then assumed to grow at $2.77 \%$ per year through retirement at age 68. Although the number of dollars they will earn during their work life is substantially greater than $\$ 766,566$, the cash they will earn throughout their work life is equivalent to receiving a lump sum of $\$ 766,566$ immediately upon graduating high school.

The following tables present the total value (NPV) of the cash flows earned by different degree areas from different schools, as well as the Education Value of a post-secondary education. Education Value represents the value the average student adds by earning a post-secondary degree, above that of the average high school graduate.

Table 2 shows the median value-added for students earning post-secondary degrees in art, business, communication, computer science, education, engineering, humanities, math, health, science, and social studies. There are significant differences across disciplines. For example, the value of an Education degree is less than a third the value of a Math degree.

TABLE 2

2018 EDUCATION VALUE

\begin{tabular}{|l|r|}
\hline Degree Area & Median Education Value \\
\hline Math & $\$ 1,496,503$ \\
\hline Computer Science & $1,390,949$ \\
\hline Engineering & $1,215,572$ \\
\hline Business & $1,014,516$ \\
\hline Science & 941,417 \\
\hline Communication & 861,778 \\
\hline Health & 751,764 \\
\hline
\end{tabular}




\begin{tabular}{|l|r|}
\hline Humanities & 749,216 \\
\hline Social Science & 724,197 \\
\hline Art & 593,894 \\
\hline Education & 431,255 \\
\hline
\end{tabular}

Table 3 reports First Year Cost, Beginning Salary, Total Value, Education Value, and Rate of Return for all degree areas and all schools ranked by Education Value. Top areas in terms of adding value are computer science, engineering, math, and business, with the top 37-degree area/school combinations adding in excess of $\$ 1,000,000$ in value over and above a high school education. It is important to note, however, that there are no bad financial choices on this list in terms of the value-added to a student's lifetime earning capacity. The lowest ranked Education Value combination, a two-year associate degree in health from Fox Valley Technical College, adds almost $\$ 150,000$ in earnings value and provides a $14.2 \%$ return on costs invested. The lowest ranked bachelor's degree, an art degree from UW Whitewater, adds $\$ 378,466$ in Education Value and provides a $13.7 \%$ return on costs invested, significantly outperforming the U.S. stock market on a long-term basis. The Rate of Return represents annually compounded returns and can be compared, for example, to the long-term average return on the U.S. stock market of approximately $10.9 \%$ annually.

Table 3 also reports the Education Value per hour of study. This figure assumes the average student spends 3 hours per week per credit hour in academic activities, including studying and attending class, needed to complete their degree successfully. Assuming the average student takes 16 credit hours per semester, this amounts to a 48-hour work week. Education Value per hour of study is calculated by dividing Education Value by the total number of hours estimated to be needed to complete a post-secondary degree. Assuming they complete their degree, this amount can be interpreted as the amount of value a degreecompleting student adds to their personal value for every hour they work toward completing their degree.

Although students earning Art degrees from all ten universities included in this study add substantial value to their lifetime earnings by earning a bachelor's degree in Art, there are significant differences in the amount of value-added based on the school from which the bachelor's degree is earned. As identified in Table 3, Art majors from UW Madison earn the highest return on their school cost investment, adding an average of $\$ 718,319$ to the value of their expected earnings on top of the $\$ 776,566$ in value the average high school graduate is expected to earn. In the process of earning their degree, UW Madison Art majors are adding $\$ 125$ per hour of study to the value of their lifetime earnings and are earning a $17.6 \%$ return on the costs of tuition, books and supplies, and other costs they paid to get their four-year Art degree. Art majors that earn bachelor's degrees from UW Whitewater are at the other end of the spectrum, adding $\$ 378,466$ to the value of their lifetime earnings over and above what the average high school graduate is expected to earn. This adds $\$ 66$ per hour of study to the value of their lifetime earnings. They are earning a $13.7 \%$ return (significantly outpacing the long-term average of the U.S stock market) on the costs of tuition, books, supplies, and other costs they paid to get their four-year art degree. Examination of valueadded within each degree area reveals substantial differences between schools.

Figure 1 shows Education Value by degree area and school. Computer Science is clearly the best valueadded major across colleges, with Business, Engineering, and Math returning well for some schools. Education has the lowest Education Value, with Art a close second. 
FIGURE 1

EDUCATION VALUE BY DEGREE AREA AND SCHOOL

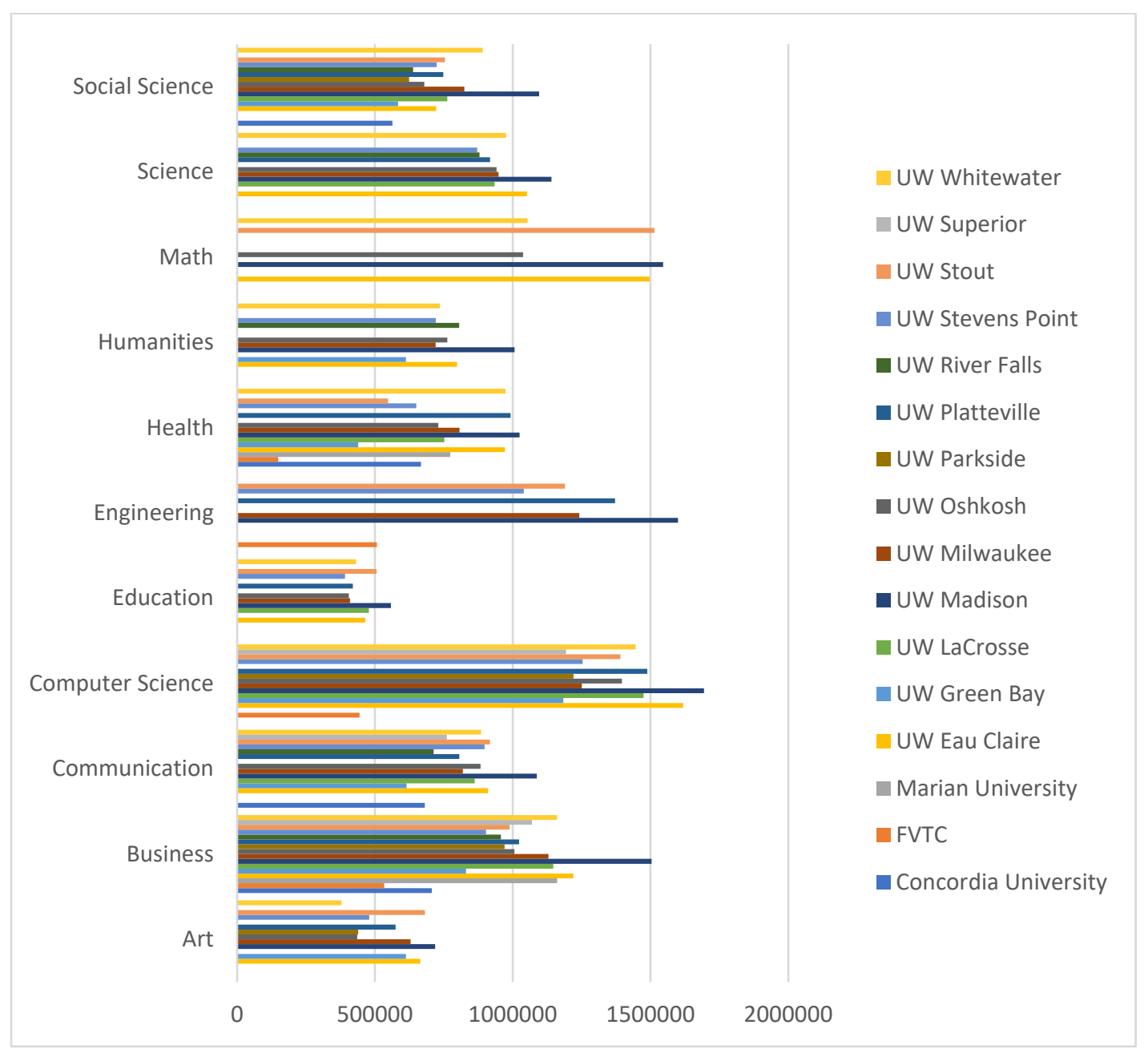

\section{CONCLUSIONS}

Although there are many nonfinancial benefits to obtaining a post-secondary degree, rapidly increasing levels of student debt make the financial value that Wisconsin students receive in return for their investment in obtaining a post-secondary degree of increasing importance. Rate of return and value-added are fundamental decision criteria for any investment, yet many Wisconsin students make education investment decisions involving potentially huge financial implications without this basic investment information. This study finds that all 115-degree area/school combinations add substantial financial value to a person's ability to earn and provide an investment rate of return that outperforms the long-term average of the U.S. stock market. The highest rate of return on degree cost in this study's sample is $29.2 \%$ for an associate degree in computer science from Fox Valley Technical College, and a computer science degree from UW Madison adds the most value to the average recipient's future earnings - a total of $\$ 1,694,086$ over and above what the value an average high school graduate is expected to earn across a lifetime. The lowest rate of return on degree cost in this sample is $13.3 \%$ for an associate degree in health from Fox Valley Technical College, and the least value-added is $\$ 149,286$ for a bachelor's degree in social science from Concordia University.

There are several shortcomings of this study, which also are opportunities for future research. The wage growth rate is an average rate across all schools and degree areas, and is assumed to be constant across a 
person's career. Intuitively it seems unlikely that these assumptions are true. If actual growth rates vary a reasonable amount (within a few percentage points), the calculated Education Values of a post-secondary degree can vary significantly (up to $\$ 200,000$ ), but the relative positions of the Education Values across schools and degree areas is unchanged. In addition, but of lesser potential impact, is that the growth rate applied to costs is a national average and is the same across all types of schools. This includes state universities, technical schools, and for-profit schools.

One conclusion of this analysis is clear - although there are significant differences in Education Value and return on cost invested across schools and degree areas, from a financial perspective, there are no bad choices on this list. Investing time, effort, and money into a postsecondary degree is a solid investment in the future. This is even more true given the vast array of non-financial benefits associated with earning a post-secondary degree. For many people, earning a post-secondary degree is the best investment they will ever make. 


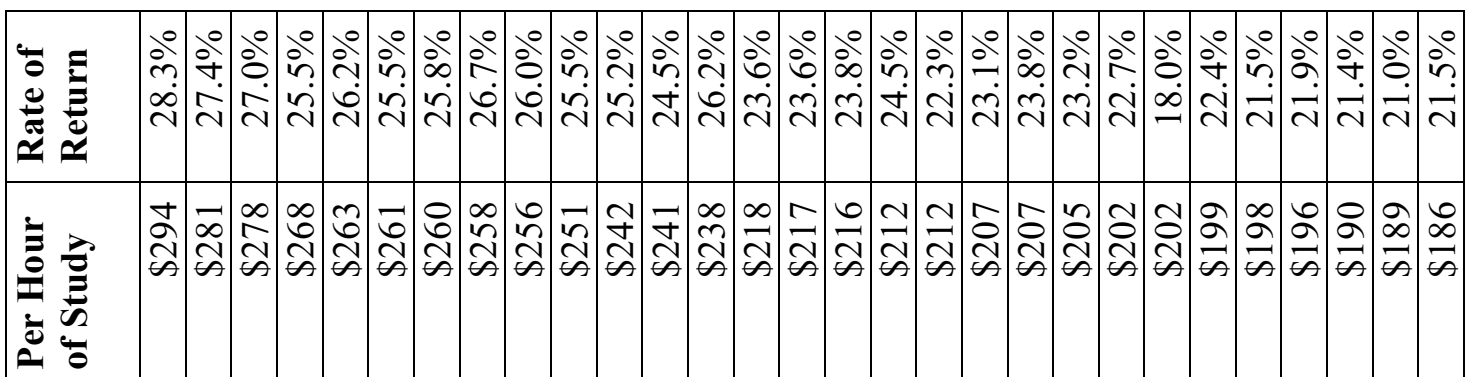

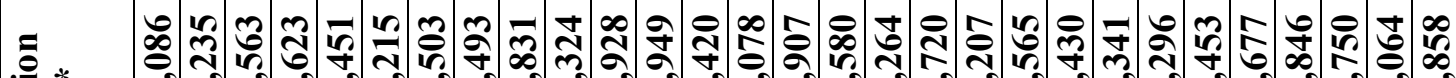

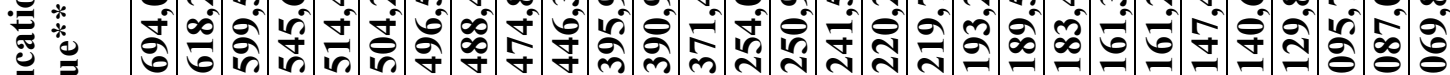

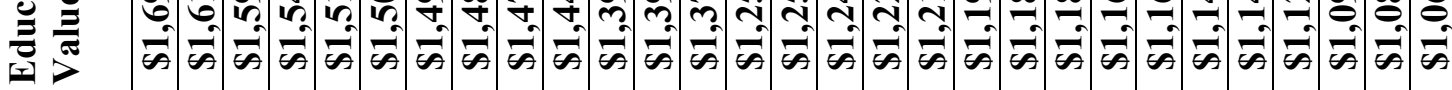
గ̂̉ స

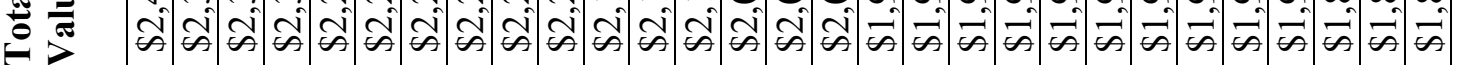
ㅇำ

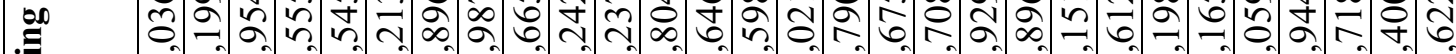
ह : ค

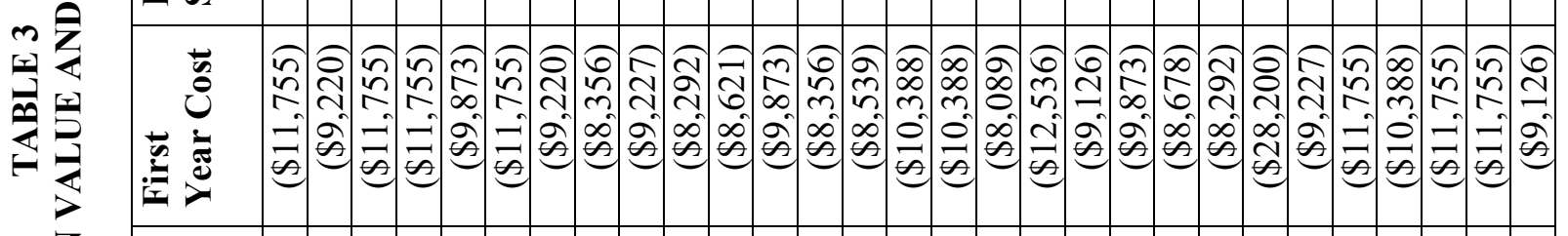

\begin{tabular}{|c|c|c|c|c|c|c|c|c|c|c|c|c|c|c|c|c|c|c|c|c|c|c|}
\hline 5 & 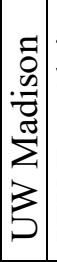 & 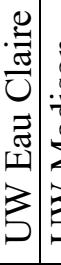 & 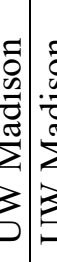 & & 3 & 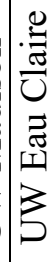 & 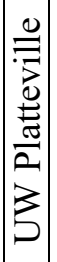 & 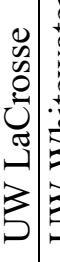 & 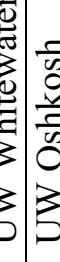 & 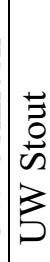 & 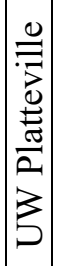 & 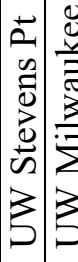 & 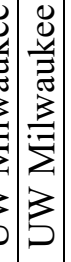 & 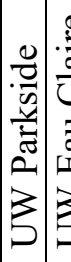 & 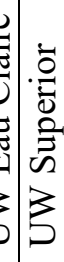 & $=$ & 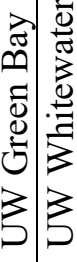 & 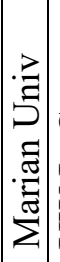 & 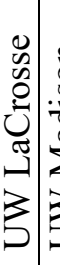 & 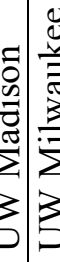 & 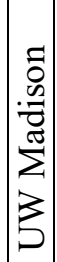 & 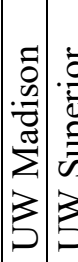 \\
\hline D. & 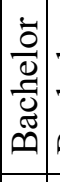 & 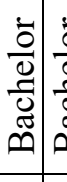 & 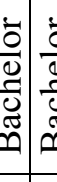 & 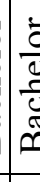 & & 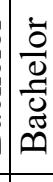 & 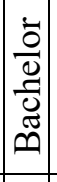 & 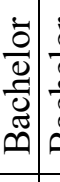 & 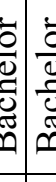 & 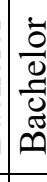 & 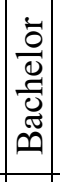 & 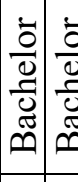 & 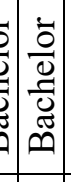 & 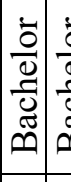 & 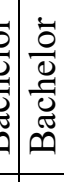 & 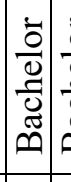 & 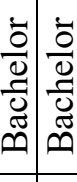 & 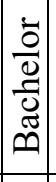 & 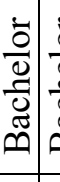 & 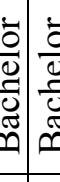 & 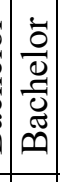 & 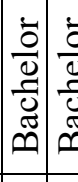 \\
\hline 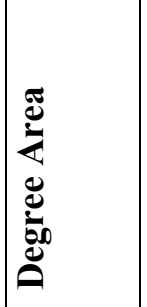 & 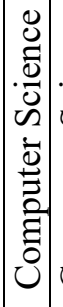 & 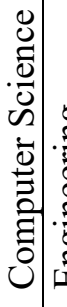 & 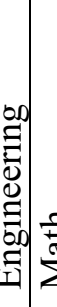 & 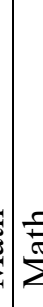 & & 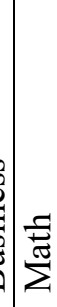 & 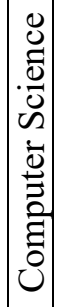 & 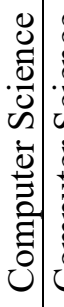 & 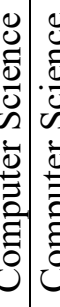 & 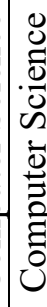 & 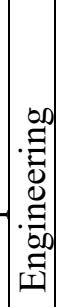 & 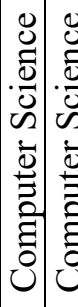 & 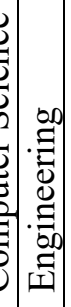 & 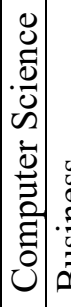 & 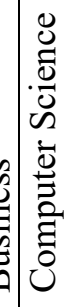 & 己. & 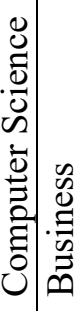 & 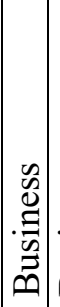 & 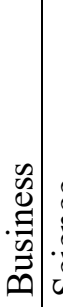 & & 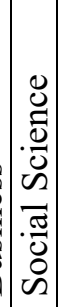 & 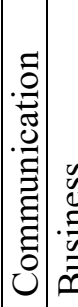 \\
\hline 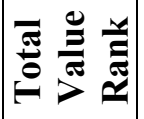 & & $V$ & $m / 7$ & & 6 & 12 & $\infty$ & $a$ & $\underline{\underline{e}}$ & 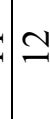 & 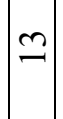 & $\pm \cong$ & 20 & $\approx 0$ & 02 & 이 & $\vec{\sim} \approx$ & & $\stackrel{\Xi}{d}$ & & $\widehat{\imath}$ & $\stackrel{\infty}{\sim}:$ \\
\hline
\end{tabular}




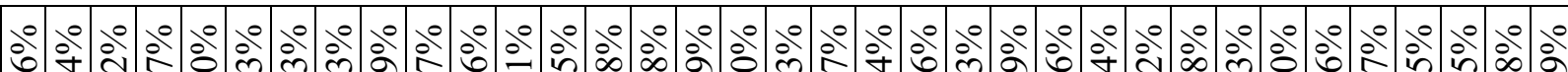

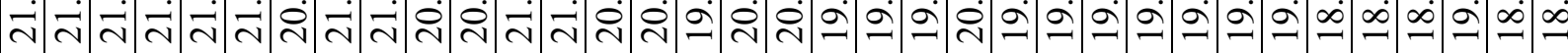

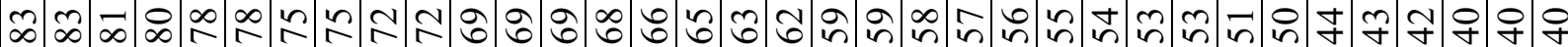

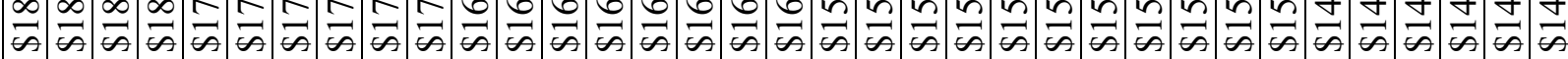

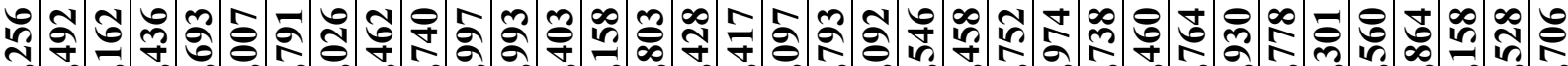

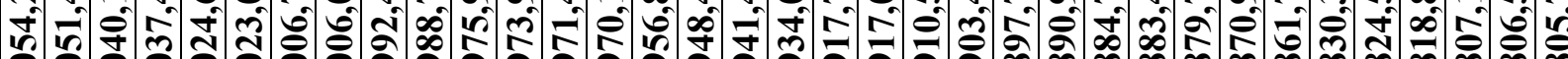

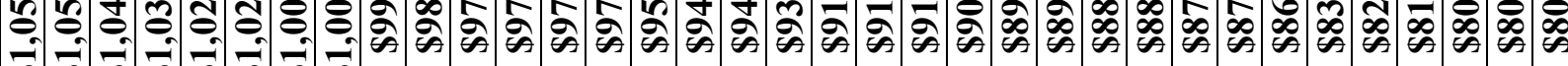 的的的的的}

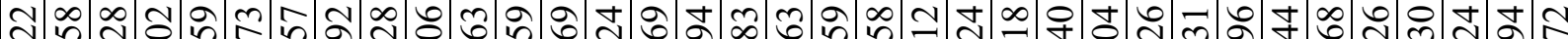

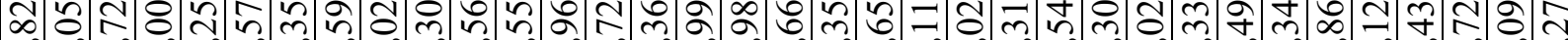
की

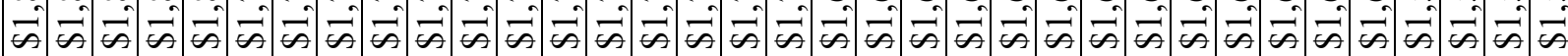

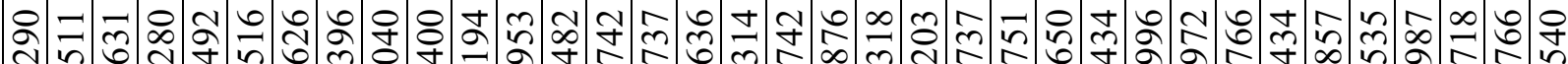

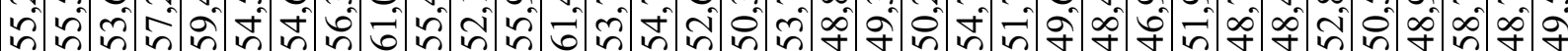

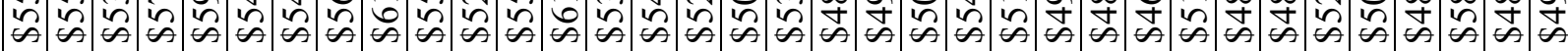

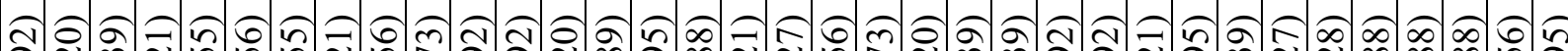

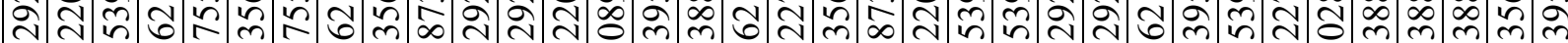

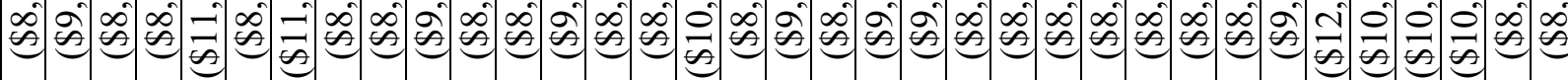

矛.

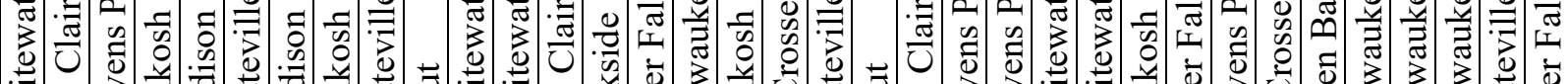

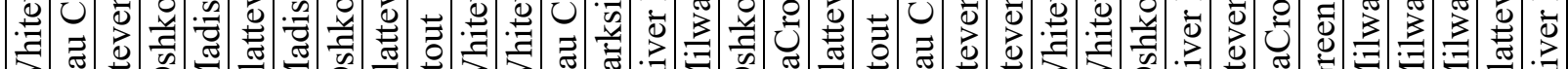

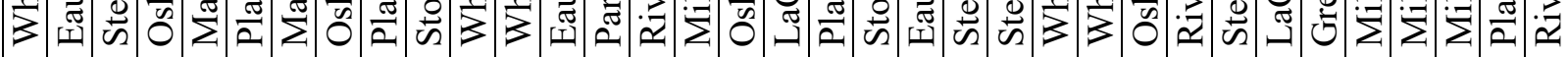

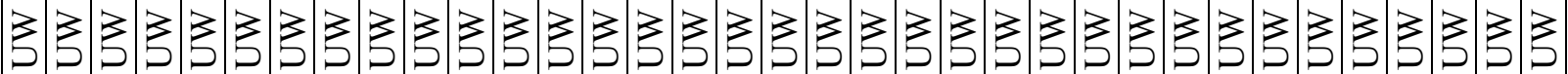

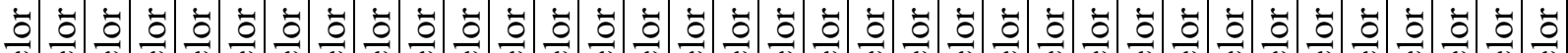

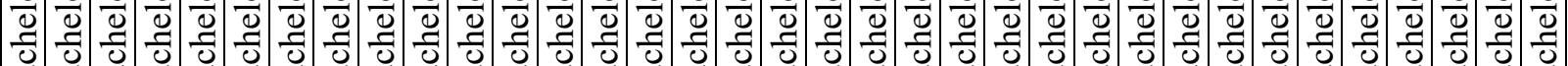

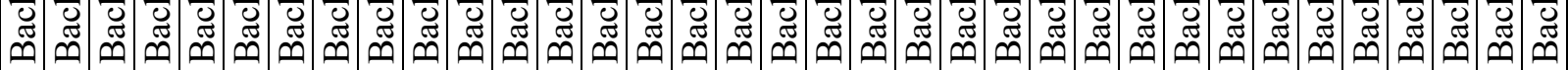

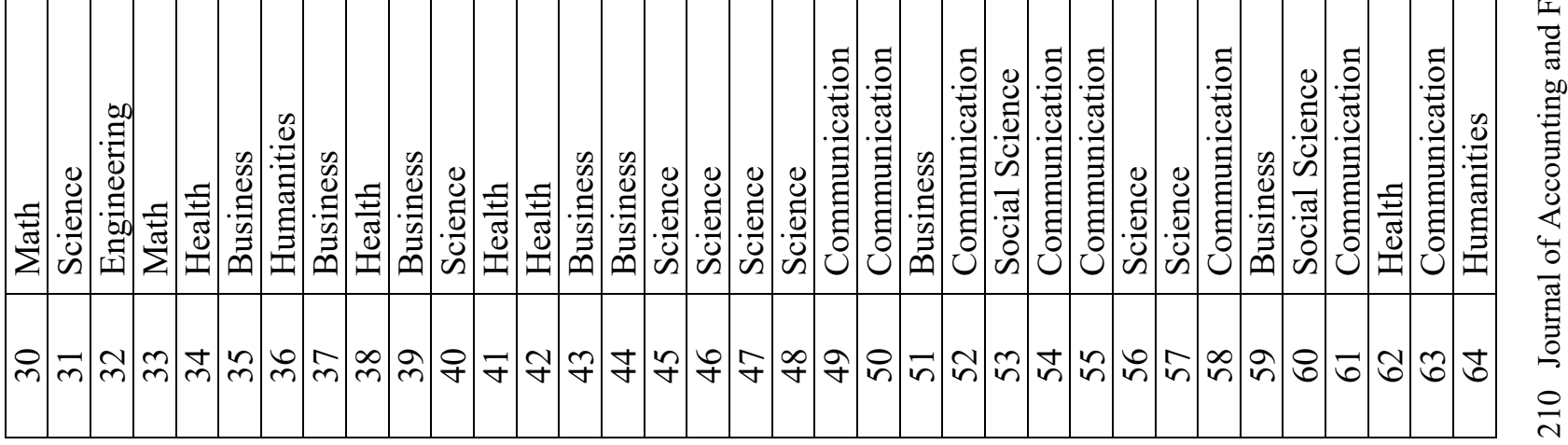




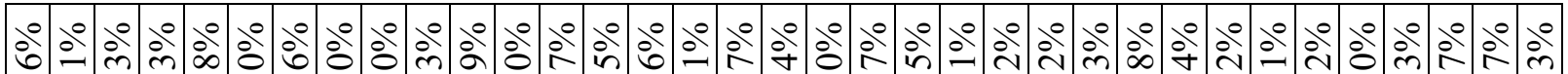

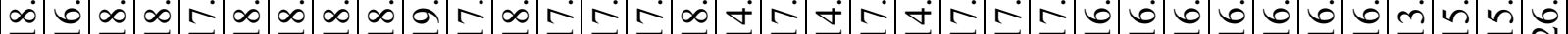

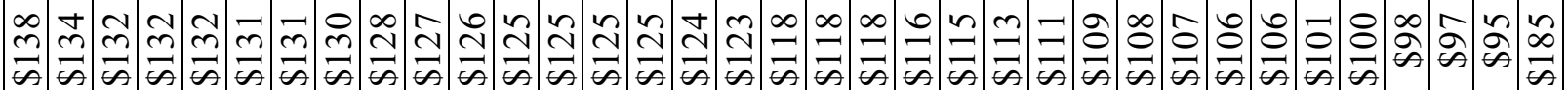

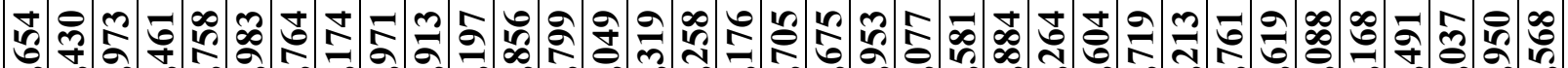
全

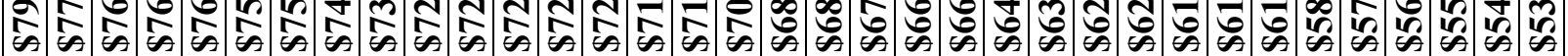

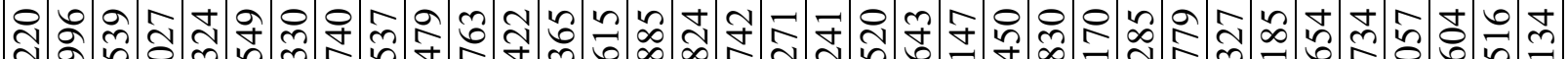
הิ

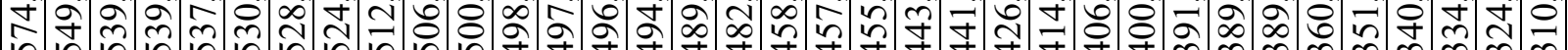

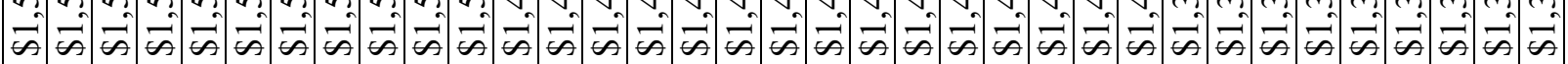

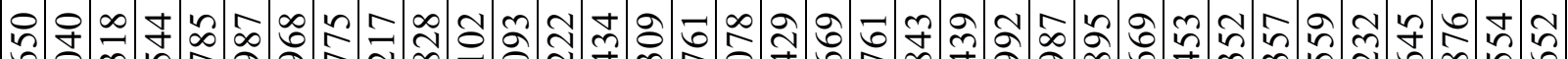

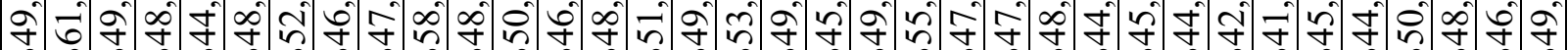

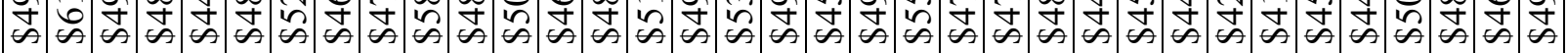

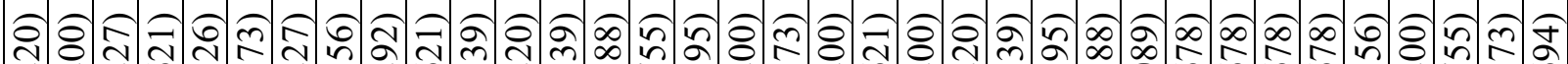

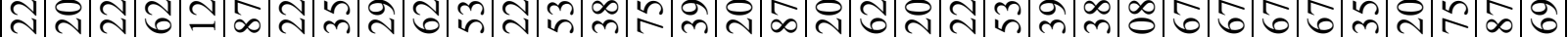

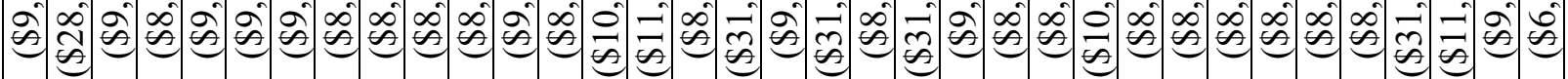

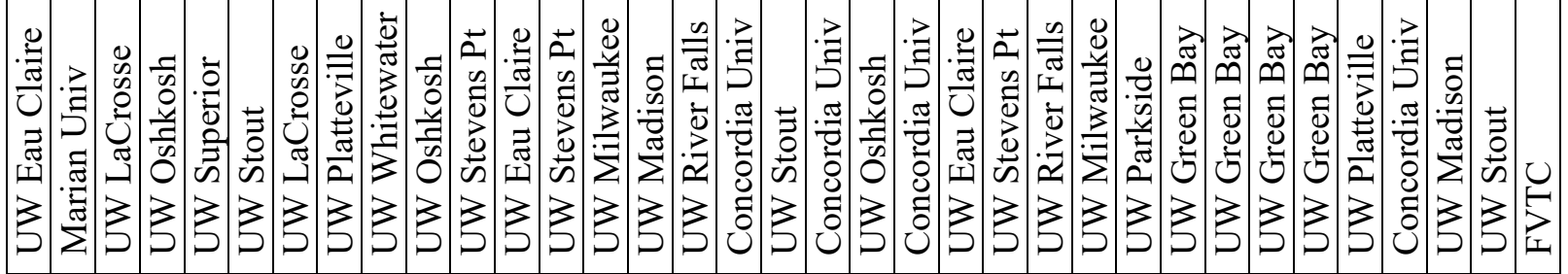

它

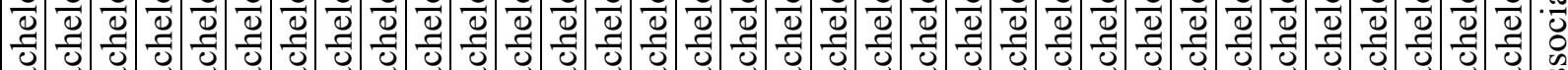

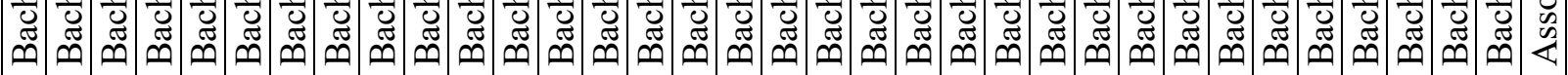

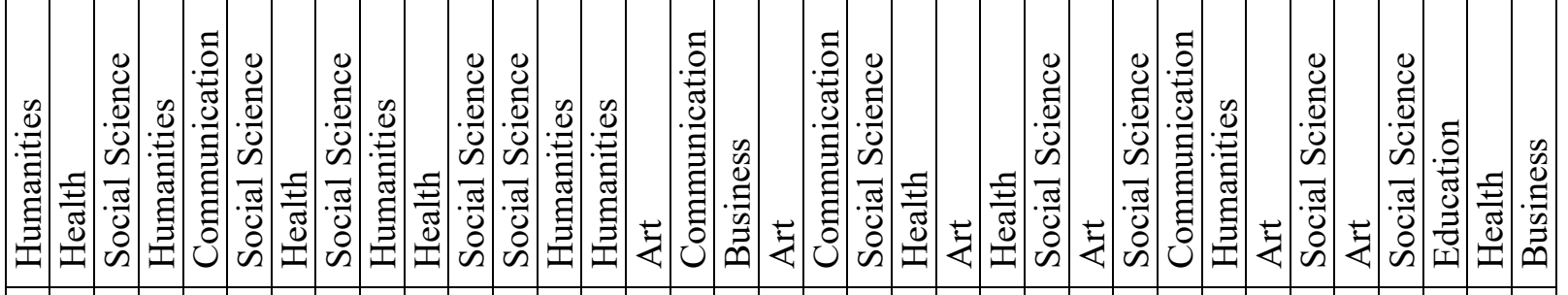

ஊேல் 


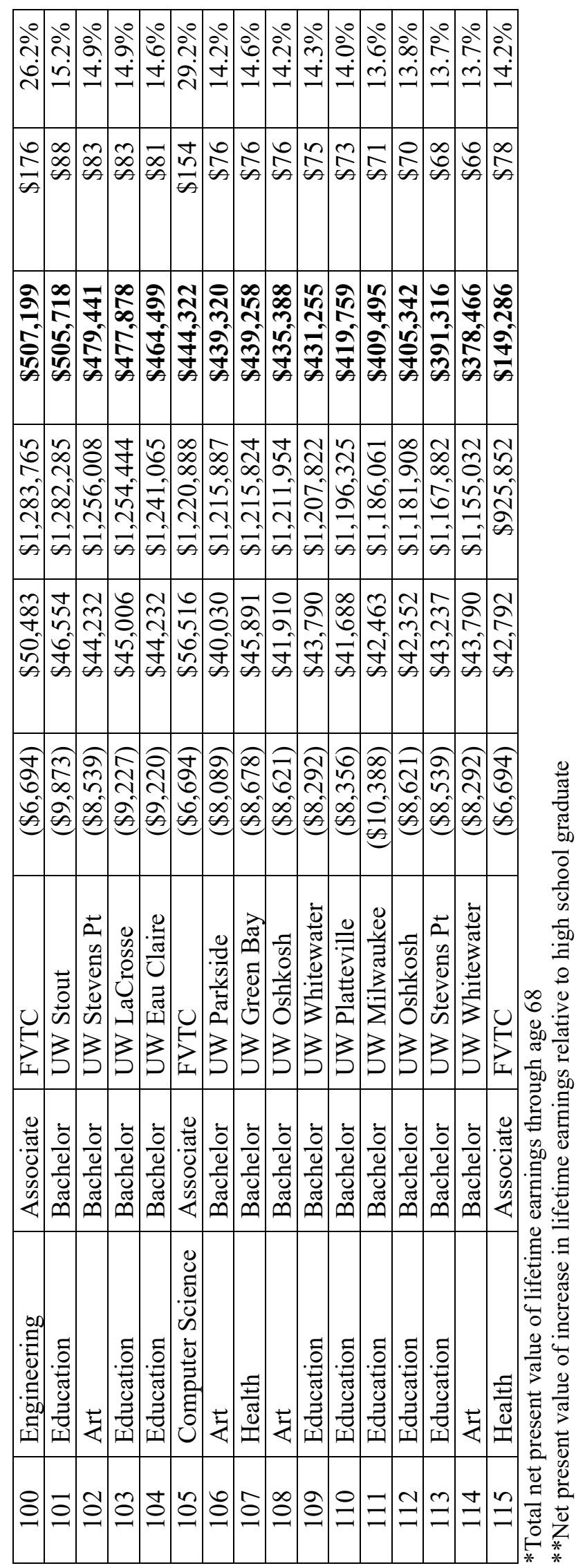




\section{ENDNOTES}

1. https://obamawhitehouse.archives.gov/sites/default/files/page/files/20160718_cea_student_debt.pdf

2. Assumes the 50-year average of the S\&P 500 index return, $1971-20 \overline{2} 0$, of $10.9 \%$, https://www.fool.com/investing/how-to-invest/stocks/average-stock-market-return/

3. https://www.fool.com/investing/how-to-invest/stocks/average-stock-market-return/

4. Federal Reserve Bank of St. Louis: https://fred.stlouisfed.org/series/SLOAS

5. https://educationdata.org/student-loan-debt-statistics

6. https://www.federalreserve.gov/publications/2019-economic-well-being-of-us-households-in-2018-studentloans-and-other-education-debt.htm

7. See, for example, Abel and Deitz (2019), Cohn and Huches (1994), Cooper and Cohn (1997), Lobo and Burke-Smalley (2018), and Wright and Ross (2021).

\section{REFERENCES}

Abel, J., \& Deitz, R. (2019). Despite Rising Costs, College Is Still a Good Investment. Federal Reserve Bank of New York. Retrieved from libertystreeteconomics.newyorkfed.org/2019/06/despiterising-costs-college-is-still-a-good-investment.html

Arias, O., \& McMahon, W. (2001). Dynamic Rates of Return to Education in the U.S. Economics of Education Review, 20(2), 121-138.

Avery, C., \& Turner, S. (2012). Do College Students Borrow Too Much - Or Not Enough? The Journal of Economic Perspectives, 26(1), 165-92.

Barrow, L., \& Malamud, O. (2015). Is College a Worthwhile Investment? Annual Review of Economics, 7, 519-555.

Bleemer, Z., \& Zafar, B. (2018). Intended College Attendance: Evidence from an Experiment on College Returns and Costs. Journal of Public Economics, 157, 184-211.

Cappelli, P. (2020). The Return on a College Degree: The US experience. Oxford Review of Education, $46(1), 30-43$.

Chakrabarti, R., Fos, V., Liberman, A., \& Yannelis, C. (2020). Tuition, Debt, and Human Capital. FRB of New York Staff Report, Staff Report No. 912.

Cohn, E., \& Huches, W. (1994). A Benefit-Cost Analysis of Investment in College Education in the United States: 1969-1985. Economics of Education Review, 13(2), 109-123.

Cooper, S., \& Cohn, E. (1997). Internal Rates of Return to College Education in the United States by Sex and Race. Journal of Education Finance, 23(1), 101-133.

Council of Economic Advisers. (2016). Investing in Higher Education: Benefits, Challenges, and the State of Student Debt. Damascus, MD: Penny Hill Press.

Dale, S., \& Krueger, A. (2011). Estimating the Return to College Selectivity over the Career Using Administrative Earning Data. Journal of Human Resources, 49(2), 323-358.

Eaton, C., Howell, S., \&Yannelis, C. (2020). When Investor Incentives and Consumer Interest Diverge: Private Equity in Higher Education. The Review of Financial Studies, 33(9), 4024-4060.

Ge, S., Isaac, E., \& Miller, A. (2019). Elite Schools and Opting In: Effects of College Selectivity on Career and Family Outcomes. Working Paper.

Giani, M., Attewell, P., \& Walling, D. (2019). The Value of an Incomplete Degree: Heterogeneity in the Labor Market Benefits of College Non-Completion. The Journal of Higher Education, 91(4).

Holland, K. (2015, December 9). The Long-Term Consequences of Student Loans. CNBC. Retrieved from https://www.cnbc.com/2015/12/08/the-long-term-consequences-of-student-loans.html

Ji, Y. (2021). Job Search Under Debt: Aggregate Implications of Student Loans. Journal of Monetary Economics, 117, 741-759.

LIMRA. (2015, May 28). LIMRA Secure Retirement Institute Study Finds Student Loan Debt a Growing Concern for Retirement Saving. Retrieved from https:/www.limra.com/en/newsroom/newsreleases/2015/limra-secure-retirement-institute-study-finds-student-loan-debt-a-growing-concernfor-retirement-saving/ 
Lobo, B., \& Burke-Smalley, L. (2018). An Empirical Investigation of the Financial Value of a College Degree. Education Economics, 26(1), 78-92.

Looney, A., \& Yannelis, C. (2015). A Crisis in Student Loans? How Changes in the Characteristics of Borrowers and the Institutions They Attended Contributed to Rising Loan Defaults. Brookings Papers on Economic Activity, 2, 1-89. doi:10.1353/eca.2015.0003

Looney, A., \& Yannelis, C. (2019). How Useful Are Default Rates? Borrowers with Large Balances and Student Loan Repayment. Economics of Education Review, 71, 135-145.

Lucca, D., Nadauld, T., \& Shen, K. (2019). Credit Supply and the Rise in College Tuition: Evidence from the Expansion in Federal Student Aid Programs. The Review of Financial Studies, 32(2), 423466.

Rothstein, J., \& Rouse, C.E. (2011). Constrained After College: Student Loans and Early-Career Occupational Choices. Journal of Public Economics, 95(1-2), 149-163.

Schanzenbach, D., Bauer, L., \& Breitwieser, A. (2017). Brookings.

Thompson, D. (2018, December 11). Does it Matter Where You Go to College? The Atlantic. Retrieved from https://www.theatlantic.com/ideas/archive/2018/12/does-it-matter-where-you-gocollege/577816/

Valero, A., \& Van Reenen, J. (2019). The Economic Impact of Universities: Evidence from Across the Globe. Economics of Education Review, 68, 53-67.

Wright, A.M., \& Ross, M. (2021). To College, Or Not To College: An Individualized Approach to Human Capital Investment. Journal of Financial Counseling and Planning, forthcoming.

Zhang, L. (2013). Effects of College Educational Debt on Graduate School Attendance and Early Career and Lifestyle Choices. Education Economics, QE89, 21, 154-175. 